INFORMASI: Kajian Ilmu Komunikasi-ISSN (p) o126-065o; ISSN (e) 2502-3837

Vol. 48. No. 2 (2018). Pp.281-293. doi: http://dx.doi.org/10.21831/informasi.v48i2.22961

\title{
MANAGING INTERCULTURAL INTERACTION AND PREJUDICE OF THE INDONESIAN COMMUNITY: AS AN EFFORT TO PREVENT AND MANAGE SARA CONFLICT
}

\author{
Ferry Adhi Dharma \\ ferryadhidharma@gmail.com \\ Universitas Muhammadiyah Sidoarjo
}

\begin{abstract}
Interaction and conflict have a very close relationship. Besides, can cause conflicts, interactions can also be used to prevent and manage conflict. There are intrigue and prejudice in dynamic social interaction. Therefore, it takes control of that assessment to others, to be honest, and rational. Individually, prejudice can be controlled through oneway and two-way communication within the family. In groups, prejudice control can be done through the establishment of institutions to communicate more transactional. Social institutions can impose sanctions on anyone proven to produce and disseminate prejudices. Moreover, social institutions can also produce and deploy a symbol of harmony through myth or a true story.
\end{abstract}

Keywords: Interaction Between Culture, Prejudice, Indonesian.

\section{MENGELOLAH INTERAKSI ANTAR BUDAYA DAN PRASANGKA MASYARAKAT INDONESIA SEBAGAI UPAYA PENCEGAHAN DAN PENANGANAN KONFLIK SARA}

\begin{abstract}
Abstrak
Interkasi dan konflik memiliki hubungan yang sangat erat. Disamping dapat menyebabkan konflik, interaksi juga dapat digunakan untuk mencegah dan menangani konflik. Ada intrik dan prasangka dalam interaksi sosial yang dinamis. Oleh karena itu, dibutuhkan pengendalian agar penilaian terhadap orang lain menjadi jujur dan rasional. Secara individu, prasangka dapat dikendalikan melalui komunikasi satu dan dua arah dalam keluarga. Secara kelompok, pengendalian prasangka dapat dilakukan melalui pembentukan institusi yang dalam berkomunikasi lebih transaksional. Institusi sosial dapat memberi sanksi pada siapapun yang terbukti memproduksi dan menyebarkan prasangka. Selain itu, institusi sosial juga dapat memproduksi dan menyebarkan simbol kerukunan melalui mitos atau kisah nyata.
\end{abstract}

Kata Kunci: Interaksi Antar Budaya, Prasangka, Masyarakat Indonesia. 


\section{PENDAHULUAN}

Indonesia adalah negara kepulauan yang kaya akan keragaman budaya. Menurut Badan Pusat Statistik Republik Indonesia (BPS RI) ada 1331 suku bangsa yang sampai saat ini diakui eksistensinya. Oleh karena itu, sangat lazim muncul semboyan "Bhineka Tunggal Ika" sebagai bentuk kesadaran bahwa bagaimanapun keragaman budaya itu, semua adalah satu, rakyat Indonesia yang memiliki kewajiban dan hak yang sama sebagai warga negara (https://www.bps. go.id/KegiatanLain/view/id/127).

Kendati demikian, ada pesimistis yang kuat akan terwujudnya cita-cita luhur yang tersurat maupun tersirat dalam semboyan luhur tersebut. Mari lihat berbagai konflik Suku, Agama, Ras, dan Antar golongan (SARA) yang terjadi di Indonesia. Semua terjadi silih berganti seperti virus yang tidak ada obatnya.

Tentu kita masih ingat dengan konflik Sunni-Syi'ah yang terjadi di Sampang, konflik Poso, Papua, Sambas, dan konflikkonflik lainnya yang sampai saat ini belum dapat diselesaikan oleh pihak manapun. Semua itu dapat dijadikan sebagai bukti bahwa Indonesia layak dimasukkan dalam daftar negara yang rawan akan terjadinya disintegrasi sosial.

Dari berbagai konflik yang sudah terjadi, rakyat Indonesia nyatanya lebih suka menyebut diri mereka berbeda, bukan beragam, apalagi sama dalam bingkai keberagaman. Jika mau teliti, kehancuran sebuah negara ataupun kerajaan tidak bisa dilepaskan dari faktor perang saudara yang terjadi dalam negara ataupun kerajaankerajaan tersebut. Majapahit misalnya, telah terjadi perang "Paregreg" yang berakibat pada melemahnya pemerintahan dan penderitaan bagi rakyat (Subroto, 2016: 4). Begitu pula yang telah-sedang terjadi di Timur Tengah dan tempat lainnya.

\section{KAJIAN PUSTAKA}

Masyarakat yang egoistis dalam memaknai perbedaan telah menghancurkan indahnya keragaman dalam suatu persamaan identitas. Sekecil apapun itu, egoisme dalam menyikapi perbedaan akan menghadirkan etnosentrisme yang berujung pada perpecahan, baik secara batin maupun fisik. Bahkan Samovar, Porter, dan McDaniel telah membagi sikap etnosentrisme menjadi tiga bagian, seperti penjelasan berikut:

"Ethnocentrism can be viewed as having three levels: positive, negative, and extremely negative. The first, positive, is the belief that, at least for you, your culture is preferred over all others. This is natural, and inherently there is nothing wrong with it because you draw much of your personal identity and many of your beliefs from your native culture. At the negative level, you partially take on an evaluative dimension. You believe your culture is the center of everything and all other culture should be measured and rated by its standards. As Triandis (1994) notes, "we perceive in group customs as universally valid. We unquestionably think that in-group roles and values are correct." Finally, in the extreme negative form, it is not enough to consider your culture as the most valid and useful; you also perceive your culture to be the most powerful one, and even believe that your values and beliefs should be adopted by other cultures." (Samovar, Porter, and McDaniel, 2010: 180).

Semakin etnosentris seseorang, maka semakin egois pula seseorang tersebut dalam menjalin hubungan dengan budaya lain. Dari sana lah akan muncul kelompok mayoritas (superior) dan kelompok minoritas (inferior) dalam maupun antar lingkungan sosial, di mana keduanya saling meragukan kebenaran pesan atau informasi yang dismpaikan oleh masing-masing kelompok.

Ada semacam gap komunikasi di antara kedua kelompok yang dapat memunculkan prasangka dan stereotip antar kelompok. Hubungan interaksi yang terjalin tidak akan tulus dan sehat. Terciptalah muatanmuatan kepentingan dalam interaksi yang melibatkan konstruksi pesan dan realitas, dimana komunikator/an akan memainkan 
simbol-simbol komunikasi dan status sosial yang dimiliki demi mendapatkan keuntungan dari interaksi yang sedang berlangsung.

Ketidaktulusan komunikasi di atas tentu saja berpotensi menghadirkan konflik sosial. Dharma (2016: 2) menunjukkan betapa rentannya terjadi konflik SARA di Indonesia. Bahkan, konflik tersebut dapat terjadi pada satu etnik, seperti yang telah terjadi di Sampang pada 26 Agustus 2012 silam antara kelompok Sunni dengan Syi'ah.

Beberapa ahli komunikasi telah sepakat bahwa perbedaan budaya dapat menghadirkankecemasandan ketidakpastian komunikasi. Kendati demikian, sangat sedikit yang melihat perbedaan tersebut sebagai pembingkai persamaan budaya di antara keberagaman yang ada. Rutherford, dkk menyatakan:

"We can use the word difference as a motif for that uprooting of certainty. It represents an experience of change, transformation and hybridity, in vogue because it acts as a focus for all those complementary fears, anxieties, confusions and arguments that accompany change. But as an approach to cultural politics it can help us make sense of what is happening: it can be a jumping-off point for assembling new practices and languages, pulling together a diversity of theories, politics, cultural experiences and identities into new alliances and movements. Such a politics wouldn't need to subsume identities into an underlying totality that assumes their ultimately homogeneous nature." (Ruthrford, J., et., al., 1990: 10).

Benar jika sangat sulit dan bahkan tidak perlu memaksakan keragaman yang ada menjadi satu budaya -homogen. Keragaman tersebut merupakan identitas-identitas budaya yang alami beserta otonomi yang dibawa secara turun-temurun. Justru dengan adanya perbedaan itu hendaknya kita belajar bahwa setiap budaya memiliki kelebihan dan kekurangan yang saling membutuhkan satu sama lain.

Mengelolah interaksi antar budaya dan prasangka menjadi penting untuk dilakukan agar terhindar dari konflik sosial. Mari berkaca pada konflik Sunni-Syi'ah yang terjadi di Sampang, Madura. Karena sejarah penindasan yang dialami, komunikasi masyarakat Madura, khususnya Sampang dan Bangkalan menjadi lebih spontan, baik verbal maupun nonverbal. Ketika masyarakat sekitar (Sampang) tidak suka dengan kelompok Syi'ah, maka yang terjadi adalah saling serang pendapat dan konflik berdarah (Dharma, 2016: 11).

Dalam hal ini komunikasi memiliki peran ganda sekaligus. Disamping sebagai salah satu faktor pemicu konflik, komunikasi juga dapat dijadikan sebagai solusi untuk menyelesaikan konflik. Oleh karena itu, dibutuhkan strategi komunikasi yang tepat agar tidak memancing konflik lanjutan.

\section{Konflik dan Transaksi Informasi Antar Budaya}

Pentingnya strategi komunikasi dalam menganalisis hubungan dan menyelesaikan konflik sosial-budaya telah menginspirasi beberapa akademisi di Indonesia untuk melibatkan komunikasi sebagai strategi penghentian konflik. Misalnya Khairil (2012: 409-430) yang menawarkan adanya komunikasi pendidikan sebagai solusi penghentian konflik Poso. Komunikasi pendidikan yang dimaksud adalah komunikasi yang terjadi dalam suasana pendidikan, yang dalam hal ini dibagi menjadi tiga aspek yaitu: komunikasi sebagai tindakan satu arah, komunikasi sebagai suatu interaksi, dan komunikasi sebagai transaksi.

Tindakan satu arah merupakan refleksi dari teori jarum hipodermik, yaitu dengan melakukan doktrinasi nilai-nilai agama dan budaya seperti halnya di wilayah Pamona Utara, yang mayoritas beragama Kristen dengan identitas etnik suku Pamona. Berlanjut pada interaksi, yang bisa disebut sebagai komunikasi dua arah. Menurut Khairil, umumnya konteks komunikasi pendidikan itu berorientasi pada kesamaan teks, perspektif yang sama sehingga interaksional komunikasi bisa berlangsung 
dalam bingkai yang sama. Hal ini dialami oleh siswa SMU Negeri 1, Poso pesisir yang mayoritas beragama Islam walaupun dengan identitas etnik yang lebih beragam.

Kemudian yang terakhir adalah transaksi. Komunikasi transaksional tersebut dicontohkan pada siswa SMU Negeri 1 yang ada di wilayah Poso Kota. Keragaman budaya dan pluralisme agama sangat dirasakan oleh siswa SMU Negeri 1 Poso Kota. Sebagai salah satu sekolah dengan tingkat keragaman agama dan budaya yang pluralis, maka sekolah ini tidak menerapkan aturan kaku dan baku khususnya dalam transformasi nilai agama dan budaya. Misalnya, bagi siswa yang beragama Kristen maka mereka dengan bebas dan leluasan tanpa merasa risih atau canggung dapat berinteraksi dengan baik kepada para siswa dengan latar agama Islam. Bahkan pada berbagai kegiatan keagamaan yang bersifat umum seperti kegiatan halal bi halal di sekolah itu juga melibatkan para siswa yang non muslim. Demikian juga halnya dengan etnik. Bagi siswa yang berlatar etnik Jawa atau Bugis dengan leluasa dapat melakukan dialektika identitas etnik tanpa merasa canggung atau malu walaupun mereka berada di tengah siswa yang memiliki identitas etnik Pamona atau etnik lokal lainnya.

Melihat penjelasan 3 konsep komunikasi di atas, maka proses adaptasi dan transaksi informasi yang baik akan dapat menjamin hubungan komunikasi antar identitas budaya menjadi equal. Hubungan komunikasi yang setara tersebut akan mengikis habis etnosentrisme yang ada dalam masyarakat Indonesia. Semua akan menganggap dirinya sama hingga sama sekali tidakmerasa berbeda dalam satu keberagaman. Dengan demikian interaksi sosial tidak dapat dipisahkan dari adanya komunikasi interpersonal di antara masyarakat.

Dengan memasukkan teori-teori komunikasi interpersonal, analisis hubungan yang dilakukan akan lebih terarah dan mendalam. Sebagai contoh, Littlejohn (2011: 230) menempatkan tradisi sibernetika pada pembahasan pertama untuk menjelaskan sebuah hubungan yang ada. Littlejohn menunjukkan jika hal yang sangat penting dan pertama kali dilakukan oleh seseorang untuk memulai hubungan ialah dengan melakukan adaptasi. Adaptasi yang dimaksud ialah penyesuaian diri terhadap umpan balik yang diberikan oleh orang lain.

Transaksi komunikasi interpersonal menekankan pada komunikasi interpersonal itu sendiri dan peran ganda asumsi seseorang saat berkomunikasi, atau dengan kata lain terjadi saling persesi saat komunikasi terjadi (Wood, 2010: 18).

Dengan demikian transaksi komunikasi bersifat dinamis dari waktu ke waktu. Perubahan dinamika tersebut disebabkan adanya perubahan pengalaman seseorang saat berinteraksi dan bertemu dengan orang yang baru seperti penjelasan dalam gambar berikut:

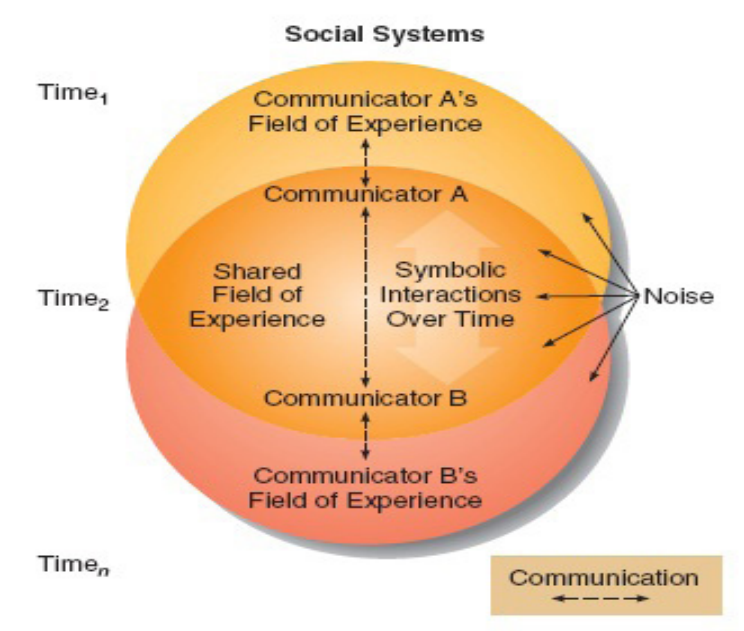

Model Transaksi Informasi Julia T. Wood (2010: 18)

Model yang digambarkan oleh Wood di atas menunjukkan bahwa pengalaman berkomunikasi sangat menentukan masa depan sebuah hubungan. Pasangan komunikasi dapat bertukar pengalaman komunikasinya untuk membentuk, menjaga, dan mengembangkan hubungan yang baik di antara mereka.

Dari gambar di atas jelas terlihat bahwa ada sumber ganguan pada semua aspek transaksi informasi yang berpotensi merusak hubungan komunikasi. Oleh karena itu, perlu adanya kesadaran bagi komunikator/ an agar terus belajar dari pengalamannya saat melakukan komunikasi dengan orang 
yang berbeda demi terciptanya hubungan yang romantis. Wood menyatakan bahwa:

\begin{abstract}
"The meanings we assign to behavior in romantic relationships are not entirely individualistic. They also reflect broad cultural views, which we learn and often internalize. For this reason, there are strong consistencies in how people socialized in the same culture and social groups attribute meaning to communication in romantic relationships." (Wood, 2010: 282).
\end{abstract}

Sering kali tindakan komunikasi seseorang merupakan internalisasi ataupun cerminan dari kebudayaan yang luas. Artinya, ada peluang untuk meginternalisasi individu dalam budaya yang sama, kelompok sosial, hingga budaya lain agar tercipta hubungan yang harmonis. Konsistensi dan strategi sosialisasi tersebut hendaknya telah dipertimbangkan secara matang karena perilaku romantis saat berkomunikasi adalah aspek yang penting dalam mewujudkan hubungan yang romantis.

Hartley (1999: 111-112) menyebutkan bahwa ada kalanya seseorang memiliki harapan agar orang lain berperilaku sesuai dengan apa yang diharapkan. Oleh karena itu, seseorang akan menggunakan cara-cara tertentu untuk mendapatkan sikap dan perilaku orang lain sesuai dengan apa yang diharapkan. Di sini lah interaksi simbolik akan berperan. Seseorang dapat memainkan simbol-simbol dalam transaksi komunikasi agar hubungan yang terjalin menjadi harmonis.

Interaksi simbolik dinyatakan dalam sebuah percakapan yang mengacu pada karakter tertentu dan yang khas dari interaksi manusia. Kekhasan yang terdiri dalam kenyataan bahwa manusia menginterpretasikan atau mendefinisikan tindakan masing-masing, bukan hanya bereaksi terhadap tindakan tersebut. Pemaknaan atau interpretasi tersebut tentu saja melibatkan stimulus dan respon (Blumer, 1969: 78-79).

Saling persepsi antar komunikator/an sangat lazim terjadi pada sebuah interaksi sosial. Pada hakikatnya, selain sebagai makhluk sosial, manusia juga makhluk yang berpikir, dan akan selalu memroses segala rangsangan atau stimulus yang diberikan.
Stimulus tersebut dapat berupa suara dan pengalaman interaksi sehari-hari. Dalam hal ini Mead (1934: 173-174) telah membahas fondasi sosial dalam diri seseorang untuk merespon perkataan orang lain. Mead secara eksplisit menelusuri konsep "I" dan "Me". Konsep ini ingin menunjukkan bahwa manusia tidak bisa lepas dari penilaian orang lain. Konsep diri kita dipandang sebagai subjek "I" yang berpikir dan menilai, sedangkan di pihak lain, kita sekaligus menjadi objek "Me" yang dipandang dan dinilai oleh orang lain. Tidak hanya melalui diri sendiri ataupun orang lain secara individual, pandangan dan penilaian terhadap diri sendiri pun juga dapat dianalisis melalui masyarakat. Masyarakat sebagai sebuah efek dari aktivitas sosialisasi antar individu, merujuk pada adanya hasil ekspektasi yang kemudian dimunculkan dalam interaksi sosial.

Konsepsi dari interaksi simbolik sendiri menekankan bahwa idividu ataupun sekelompok masyarakat memiliki hasrat subyektif untuk terlihat lebih baik dari yang lain. Kendati demikian, simbol-simbol yang dikomunikasikan dapat dikonstruksi untuk tujuan yang baik demi keutuhan suatu hubungan yang telah terjalin.

Jika masyarakat Indonesia tidak egois dalam menjalin hubungan, maka pengalamanpengalaman interaksi antar budaya yang baik akan tercipta. Sudah saatnya masyarakat Indonesia sadar bahwa Indonesia memiliki keragaman suku-bangsa, yang tentu saja melahirkan banyak perbedaan dalam menjalin komunikasi. Misalnya kebudayaan Jawa yang menggunakan budaya tinggi dalam berkomunikasi. Masyarakat Jawa cenderung untuk tidak memberi respon atau feedback komunikasi secara spontan, seperti beberapa masyarakat yang menggunakan budaya rendah dalam berkomunikasi, seperti masyarakat Batak, Madura, dan lainnya.

Dalam pandangan ilmu komunikasi, perbedaan tersebut dapat diartikan sebagai sebuah kontradiksi. Baxter (1988) dalam Kerdchoochuen (2011-10) mengusulkan beberapa tanggapan untuk kontradiksi yang terjadi pada interaksi sosial yang dinamis. Interaksi tersebut berlawanan satu sama lain dengan tidak kompatibel.

Ada tiga strategi atau tanggapan yang 
ditawarkan oleh Baxter. Pertama adalah strategi untuk memilih. Strategi ini dilakukan ketika mitra komunikasi memilih tindakan yang menudukung polaritas satu kontradiksi mereka. Strategi kedua adalah pemisahan, yang diambil ketika komunikasi interpersonal yang terjadi mengalami ketegangan. Strategi ini berbentuk sebuah perputaran dan segmentasi, dimana seseorang dapat memilih akan mengungkapkan atau merahasiakan sebuah informasi karena alasan tertentu. Kemudian strategi yang ketiga adalah pembingkaian kembali integrasi. Ini merupakan upaya untuk mendefinisikan kembali suatu kontradiksi agar tidak terjadi perpecahan. Hal tersebut dapat ditempuh dengan mengorbankan pesan dan menggunakan pesan yang ambigu untuk mengkaburkan sikap mendukung atau tidak mendukung.

Inti dari pembingkaian hubungan interaksi yang ditawarkan oleh Montgomery dan Baxter di atas adalah sikap mengalah dan cerdas dalam berkomunikasi. Dalam hal ini dibutuhkan pengetahuan serta pengalaman yang cukup untuk mengetahui simbol-simbol apa saja yang dapat memunculkan disintegrasi akibat interaksi tersebut.

Hendaknya tiap individu sadar bahwa apa yang dilakukan juga dinilai oleh orang lain. Oleh sebab itu, kebijaksanaan dalam menilai diri sendiri dan orang lain diperlukan untuk menumbuhkan rasa simpati dan empati antar individu atau masyarakat.

Dibutuhkan dialektika dengan diri sendiri secara matang. Seseorang dapat selalu bertanya pada diri sendiri tentang kebenaran dari tindakan yang akan dilakukan. Dengan berdialektika, seseorang akan lebih bijaksana dalam bertindak dan berargumen.

Smith (1977: 42) menyatakan bahwa sesungguhnya manusia tidak lahir dengan pemahaman yang jelas mengenai siapa diri mereka. Sebaliknya, manusia sndiri yang mengembangkan diri pada saat berkomunikasi dengan orang lain. Seperti saat kita memutuskan untuk mengimpor, atau menginternalisasi perspektif orang lain untuk diri kita, sehingga kita dapat saling mengenal perspektif masingmasing, dan mengetahui siapa diri kita yang sebenarnya.

Pendapat di atas menunjukkan jika proses interaksi simbolik juga kuat terjadi pada diri sendiri. Yang mana telah dicontohkan dengan seorang bayi yang semula tidak mengathui apaapa hingga dapat mengetahui siapa diri mereka setelah melalui proses dialogis di dalam dirinya.

Selalu bertanya pada diri sendiri juga dapat menumbuhkan sikap evaluatif dan komunikatif. Setiap orang akan dengan cepat dan cerdas merespon adanya indikasi perpecahan pada sebuah hubungan dengan mengevaluasi pengalamannya saat menjalin hubungan komunikasi dengan orang lain. Artinya, penilaian dan penalaran tersebut akan selalu bekerja pada diri seseorang saat berinteraksi dengan orang lain.

\section{METODE}

Artikel ilmiah ini disusundengan metode studi literatur. Analisis yang dilakukan tidak didasarkan pada studi lapangan, melainkan analisis kajian pada sejumlah literatur, baik melalui sumber pustaka buku, jurnal, maupun sumber relevan lainnya, sehingga semua jenis data yang digunakan bersifat sekunder. Lebih lanjut, analisis dalam penelitian ini difokuskan pada kajian terhadap pengelolahan interaksi antar budaya dan prasangka masyarakat Indonsia sebagai salah satu upaya pencegahan dan penanganan konflik SARA yang terjadi di Indonesia.

\section{HASIL DAN PEMBAHASAN}

\section{Mengendalikan Prasangka pada Individu Hingga Kelompok}

Penghargaan antara kelompok mayoritas dan minoritas mutlak diperlukan. Dalam beberapa kasus, kelompok minoritas adalah kelompok yang rentan dijadikan obyek prasangka buta bagi kelompok mayoritas, begitu juga sebaliknya. Ujung dari prasangka sendiri adalah tindak diskriminatif yang dapat merusak hubungan sosial. Oleh karena itu, perlu kiranya ada semacam kontrol prasangka untuk menghindari perang prasangka yang dapat berujung pada perpecahan dan konflik sosial.

Menurut Bodenhausen, et., al (2009: 115) 
ada nilai-nilai pribadi yang mempengaruhi setiap orang untuk yakin bahwa prasangka yang ada dalam pengetahuannya adalah salah dan sehingga tidak mengungkapkan prasangka tersebut pada orang lain. Keinginan untuk bertindak atas nilai-nilai ini terlepas dari insentif eksternal atau sanksi ini disebut motivasi internal untuk mengendalikan prasangka.

Ada dua faktor penting untuk mengendalikan prasangka seseorang terhadap budaya lain, yaitu: motivasi internal yang bersumber pada sifat dan sikap tiap individu dan insentif eksternal atau sanksi yang bersumber pada lingkungan sosialbudaya.

Nilai-nilai pribadi sendiri dapat dilahirkan dan dibentuk melalui keluarga. Dalam skala yang lebih besar, keluarga adalah ruang sosialisasi pertama dan terpenting bagi seseorang untuk memperoleh keyakinan dan nilai-nilai budaya yang dijalankan dalam sistem keluarga. Sebuah keluarga dapat mengaplikasikan nilai-nilai budaya seperti pengambilan keputusan mengenai pekerjaan yang melibatkan jender, dinamika kekuasaan, dan hubungan sosial dengan orang lain dalam pengaturan suatu budaya (Ting-Toomey, 1999: 37).

Selain melaui keluarga, seseorang juga dapat menghindarkan diri dari prasangka dengan mengkomunikasikan simbol-simbol kasih sayang secara pribadi pada orang lain dan lingkungan sosialnya. Kory Floyd dalam bukunya yang berjudul Communicating Affection Interpersonal Behavior and Social Context menyebutkan bahwa:

"In established relationships, including those among romantic partners, friends, family members, and even social acquaintances, affectionate communication is linearly and strongly related to a number of positive relational qualities. Relationships characterized by frequent affectionate behavior tend to be closer, more satisfying, and more engaging than those that are not." (Floyd, 2006: 186).

Hubungan yang dibangun dengan komunikasi kasih sayang dapat meniscayakan kualitas hubungan yang positif dan romantis. Perilaku kasih sayang akan membuat hubungan lebih dekat, memuaskan, dan menarik simpati orang lain yang sebelumnya tidak melakukan hal tersebut.

Dari sana lah akan tercipta keintiman komunikasi yang dapat menghindarkan prasangka dalam menjalin hubungan komunikasi. Jarak komunikasi interpersonal dengan masyarakat menjadi lebih dekat dan jujur hingga timbul rasa saling membutuhkan satu sama lain sebagai makhluk sosial.

Keasadaran ataupun motivasi diri tersebut dapat diperkuat dengan adanya sanksi sosial dari masyarakat. Lingkungan sosial dapat dijadikan sebagai institusi yang berwenang untuk memberi sanksi sesuai norma ataupun aturan yang dibuat bagi siapapun yang mengatakandan menyebarkan prasangkanya kepada orang lain. Sanksi tersebut dapat dijatuhkan pada seseorang jika terbukti mengatakan dan menyebarkan prasangka yang tidak benar dan mengancam integrasi sosial dalam masyarakat.

Institusi sosial yang ideal beranggotakan tokoh-tokoh masyarakat yang netral atau tidak memihak. Netralitas mutlak diperlukan agar keputusan yang diambil bijak dan apa adanya. Dengan netralitas itu semua elemen masyarakat akan terlindungi dari sentimen pribadi dan intrik-intrik sosial.

Mari berkaca pada pembentukan institusi sosial yang ditulis oleh Ilyas (2014: 1213-1227). Ilyas melakukan penelitian di Sigi, Sulawesi Tengah yang terkenal karena perang antar desanya. Polda Sulawesi Tengah mencatat, setidaknya telah terjadi 6o konflik di daerah tersebut yang berlangsung secara periodik dan menempati urutan pertama sebagai daerah yang sering konflik.

Hasil penelitian ini mengungkapkan penyebab terjadinya konflik di Sigi, sebagai berikut: (1) klaim batas wilayah dari nilai historis masing-masing, (2) orang tua menggambarkan pada anaknya jika petarung dalam konflik tersebut adalah pahlawan, (3) penegakan hukum yang rendah dari pemerintah, (4) banyaknya pengangguran yang frustasi, (5) pergeseran konflik pribadi 
menjadi konflik kelompok, (6) terbatasnya ruang pulik dan pembinaan generasi muda, (7) bias dan distorsi informasi.

Dari 7 (tujuh) poin hasil penelitian yang diungkapkan, ada 3 (tiga) poin hasil penelitian yang sangat erat hubungannya dengan kajian komunikasi. Tiga poin tersebut adalah pergeseran skala konflik, terbatasnya ruang publik, bias dan distorsi informasi.

Pertama mengenai pergeseran skala konflik. Dalam penelitian ini dijelaskan jika ada manipulasi simbol-simbol permasalahan pribadi yang ditransferkan menjadi simbol-simbol komunal. Dengan demikian simbol-simbol ini dapat dijelaskan secara komunikatif jika memasukkan pendekatan komunikasi secara mendalam.

Kedua, rendahnya kesadaran untuk membina komunikasi yang equal dengan memelihara ruang publik. Hal ini menyebabkan adanya jarak di antara kelompok yang berkonflik. Selain itu pembinaan generasi muda tidak dapat direalisasikan akibat rendahnya iklim delibratif atau musyawarah lintas generasi di lokasi konflik.

Ketiga, bahwa konflik yang terjadi dipengaruhi oleh faktor bias dan distorsi informasi. Media yang digunakan dalam menyebarkan bias atau distorsi informasi biasanya bersumber dari: desas-desus atau cerita dari mulut ke mulut yang kadangkala berbentuk gosip, pesan singkat (SMS) gelap, hingga media cetak maupun elektronik.

Dalam penelitian ini juga ditawarkan alternatif resolusi konflik, yakni perlunya dibentuk dewan adat sebagai payung perdamaian dan pemegang kekuasaan dalam menentukan nilai-nilai dan aturan yang mengikat semuanya.

Pembentukan lembaga adat ini sebenarnya sudah dilakukan oleh beberapa daerah rawan konflik. Misalnya dalam konflik Ambon, di mana Gubernur Sulteng telah membuat Pusat Rujuk Sosial (PRS), yang dalam hal ini juga menyangkut lembaga adat. PRS sendiri awalnya beranggota 6 tokoh dari berbagai Agama: Islam, Kristen, dan Katholik. Kemudian PRS semakin membesar dengan mengikutsertakan kalangan ahli, birokrasi, tokoh agama, dan para kepala adat, dan Lembaga Swadaya Masyarakat (LSM), yang kesemuanya dinilai efektif dan mampu meredam konflik Ambon (Gono, 2001: 88).

Kendati dinilai sebagai strategi yang efektif dalam menangani konflik sosialbudaya, namun PRS belum tersentuh oleh akademisi ilmu komunikasi. Oleh karenanya PRS hanya bersifat politis dan elitis.

Dalam pandangan ilmu komunikasi, strategi penerapan kekuasaan atas individuindividu, kelompok, dan masyarakat tidak cukup menekan individu agar bersedia menyesuaikan diri dengan stereotip komunikasi dan perilaku yang diinginkan. Menurut Anne Hill, dkk (2007:36) ada dua hal penting yang dapat dilakukan oleh seseorang yaitu: produksi mitos, dan penyebarannya.

Dalam hal ini Ernest Bormann, John Cragan, dan Donald Shields mengembangkan teori konvergensi yang dilandasi oleh pemikiran ahli semiotika "Charles Sanders Pierce" menjadi konvergensi simbolis atau Symbolic Convergence Theory (SCT), yang membahas bagiamana individu-individu, dalam kelompok, datang untuk membagi realitas komunikasi. Gambaran mengenai realitas tersebut dipandu oleh cerita-cerita yang menunjukkan bagaimana objek harus dipercaya secara komunal (Littlejohn, 2011: 206).

Teori konvergensi simbolis komunikasi (Bormann, 1985; Bormann, Cragan, \& Shields, 1994) banyak mewarisi disiplin ilmu akuntansi yang berisikan proses-proses dalam menciptakan dan mempertahankan kelompok atau kesadaran organisasi. Teori konvergensi simbolik (SCT) menyumbang pengembangan visi retoris, simbolik secara umum turut mengambil bagian dalam membuat visi, penciptaan, peningkatan, dan mempertahankan kelompok atau kesadaran masyarakat. Teori ini menempatkan audien komunikasi di tengah paradigma komunikasi dan menggabungkan semua unsur dari situasi komunikasi termasuk pembicara atau sumber pesan, pesan, konteks, dan audien (Bormann, Knutson, Musolf, 1997: 254-255). 
Melalui cerita-cerita fiksi ataupun keadaan yang nyata, seseorang dapat mempengaruhi orang lain untuk percaya mengenai cerita-cerita yang diberikan. Terlebih jika yang dipengaruhi atau audien memiliki pengetahuan dan kecerdasan di bawah seseorang yang mempengaruhi, maka akan ada kemungkinan cerita-cerita tersebut dengan mudah diterima dan dipercaya.

Melihat bahwa dalam komunikasi antar budaya terdapat iri dengki, prasangka, fitnah, sinis, dan lainnya, cerita-cerita simbolis akan dikonstruksi sebagai pembingkai hubungan yag harmonis. Salah satu wujud dari ceritacerita adalah mitos dan upacara keagamaan. Mitos ini hendaknya sangat melekat pada kehidupan sosial dan budaya. Mitos dan dongeng tumbuh subur dengan membawa pengaruh pada kognisi dan tindakan dari penerima pesan.

Mitos sediri memiliki banyak fungsi. Mitos menurut Cohen mempunyai beberapa fungsi, yaitu: untuk menerangkan, menyatakan, menjaga solidaritas dan kesatuan, mitos mengabsahkan, mengkomunikasikan secara tidak sadar keinginan-keinginan dan konflik, mitos sebagai penengah dalam pertentangan, dan mitos memberikan cerita waktu yang lalu pada saat sekarang (Bolman, 1988, dalam Muhammad, 2005: 62).

Mitos dapat disampaikan melalui dakwah-dakwah agama. Faktanya, agama menempati sisi kepercayaan yang paling dalam pada pemeluknya, dan tentu saja akan mudah diinternalisasikan pada pemeluk agama secara cepat. Hal tersebut sangat mungkin direalisasikan, mengingat masih banyak masyarakat Indonesia yang percaya pada mitos dan cerita-cerita lama.

Pendapat di atas dapat dipahami bahwa mitos merupakan aspek yang sangat mempengaruhi stereotip-stereotip seseorang terhadap individu ataupun budaya yang lain. Oleh sebab itu, cerita-cerita dapat dirangkai kembali untuk mempengarhi kognisi masyarakat dalam mewujudkan perdamaian. Jalan yang dapat diambil adalah menggunakan pemimpin opini untuk meneruskannya pada masyarakat yang dipimpin.

Perlu diketahui jika fokus utama dari SCT terletak pada hubungan antara pesan yang mendramatisir, rantai fantasi dari berbagai drama, dan grup fantasi yang dihasilkan secara bersama-sama. SCT melingkupi semua konteks komunikasi, di mana komunikator menghasilkan pesan yang dramatis pada audien komunikasi, dalam kondisi yang bagaimana, dan keterlibatan audien dalam aksi dramatisasi. Ada beberapa aspek dalam pesan dramatis yang dapat membuat audien menangkap dan memfokuskan perhatiannya pada pesan tersebut hingga audien berimajinasi dan bertindak sesuai dengan rangsangan pesan yang dibuat. Oleh karena itu, konsep utama dari teori ini adalah pesan yag didramatisasi dengan baik (Bormann, Knutson, Musolf, 1997: 254-255).

Formulasi akhir Bormann, dkk terdiri dari empat dimensi dasar: (1) dimensi realitas, (2) dimensi waktu, (3) dimensi moral, dan (4) dimensi emosional. Dimensi realitas dapat dilihat dari baik-tidaknya cerita fiktif atau nonfiktif yang dibuat, nyata atau tidak nyata. Ini termasuk dalam kategori yang aneh, kategori fiksi realistis, dan kategori nonfiksi realistis. Bormann, dkk mendefinisikannya sebagai narasi aneh yang berisi mengenai hal-hal yang mustahil, membuat penasaran, aneh, tidak normal, tidak wajar, menyimpang, mengerikan, mistis, mengenai dunia lain, luar biasa, ajaib, atau ilusi (Bormann, Knutson, Musolf, 1997: 259).

Realitas sendiri dibedakan menjadi dua. Ada realitas fiktif dan realitas nonfiktif. Realitas fiktif sendiri dapat dipahami sebagai realitas semu atau palsu. Ini lebih mirip dengan mitos yang sudah dijelaskan di atas. Sesuai dengan namanya (fiktif), maka realitas ini sengaja dikonstruksi untuk meyakinkan hal yang sebenarnya tidak nyata adanya menjadi nyata atau tampak nyata.

Kemudian realitas nonfiktif atau fakta. Realitas ini adalah kenyataan, atau cerita yang benar adanya. Melihat bahwa realitas ini berada dalam kajian konvergensi simbolis, maka realitas juga sengaja diceritakan untuk 
memberikan pengaruh agar audien atau patisipan komunikasi percaya dan melakukan apa yang diinginkan oleh kounikator.

Cerita-cerita yang diceritakan tidak terlepas dari dimensi waktu. Seperti pada umumnya, dimensi waktu ini dibagi atas masa lalu, masa sekarang, dan masa depan. Masa lalu berisikan cerita-cerita yang ada di masa lalu seperti dongeng, mitos, dan lainnya. Sedangkan masa sekarang adalah apa yang terjadi saat ini, dan masa depan merupakan cerita-cerita yang ditujukan untuk memberi harapan perdamaian pada audien.

Borman, dkk juga membagi dimensi moral dalam teori konvergensi simbolis. Dimensi moral adalah narasi yang terdiri dari pertanyaan dan jawaban benar-salah, etis dan tidak etis, tepat dan tidak tepat, terhormat dan tidak terhormat, berprinsip dan berprinsip. Dimensi moral termasuk kategori moral sentimental, kategori moral intelektual, dan kategori bermoral. Bormann, dkk mendefinisikan moral-sentimental sebagai dramatisasi yang menggambarkan skenario melo, sederhana, dan istilah hitam-putih yang jelas menyatakan nilainilai moral yang terlibat. Kemudian moral intelektual terdiri dari cerita yang rumit di mana tokoh protagonis kadang menang dan kadang-kadang kalah. Karakter hidup di dunia yang rumit di mana hal-hal yang tidak pernah hitam dan putih, tidak pernah jelas baik atau jahat. Cerita-cerita dibuat dengan pendekatan etika. Sedangkan kategori bermoral adalah cerita-cerita amoral yang diceritakan secara terpuji dan bermoral (Bormann, Knutson, Musolf, 1997: 260).

Kedekatan mitos dengan karakter budaya menjadi penting untuk diperhatikan. Untuk menyebut efek dari cerita-cerita yang disampaikan, Bormann, dkk menyebutnya sebagai dimensi emosional. Dimensi ini meliputi segala perasaan yang ditimbulkan dari cerita-cerita yang sengaja disampaikan, seperti bahagia-sedih, dan lainnya.

Selain itu, pemimpin opini hendaknya juga memperhatikan ritme proses sosial yang ada secara hati-hati. Dibutuhkan keahlian komunikasi yang mumpuni dari pemimpin opini agar dapat meniscayakan realitas yang diinginkan, karena konvergensi simbolis bukan sekedar retorika, meskipun terlihat sama.

Bungin (2014: 58) menyebutkan ada dua bentuk proses sosial yang terjadi di masyarakat, yaitu proses sosial asosiatif dan proses sosial disosiatif. Di mana keduanya akan selalu ada dalam interaksi sosialbudaya.

Proses sosial asosiatif berwujud kerja sama antar masyarakat dalam rangka mencapai tujuan bersama. Contohnya ketika sekelompok masyarakat saling gotong royong, toleransi, dan bekerja sama dalam kehidupan sehari-hari. Sedangkan proses sosial disosiatif merupakan kebalikan dari proses sosial asosiatif, di mana ada persaingan di antara keduanya, tidak ada toleransi, dan akhirnya dapat berbentuk konflik.

Jelas bahwa tujuan dari konvergensi simbolis ini ialah mewujudkan masyarakat Indonesia yang asosiatif. Artinya, segala cerita yang dikomunikasikan hendaknya mengakomodasi elemen-elemen dari keragaman budaya yang ada dalam suatu kelompok masyarakat.

Sebagai pertimbangan, Triandis dalam Samovar, Porter, \& McDaniel (2010: 23) telah mendefinisikan budaya sebagai hasil ciptaan manusia yang elemen-elemen objektif dan subjektifnya berasal dari masa lalu. Hal tersebut kemudian ditambahkan ataupun dimasukkan pada aspek kehidupan seharihari dan dapat digunakan untuk memenuhi para partisipan (masyarakat setempat) dalam ekologi masyarakat. Aspek-aspek kehidupan berbudaya tersebut dikomunikasikan pada masyarakat yang memiliki bahasa yang sama dan hidup di waktu dan tempat yang sama.

Jika budaya diidentikkan dengan peristiwa yang telah terjadi di masa lalu, maka hendaknya cerita yang diberikan oleh pemimpin opini tidak melupakan peristiwaperistiwa masa lalu yang telah dialami oleh masyarakat.

Cerita-cerita masa lalu sendiri tidak dapat dilepaskan dari mitosyang berkembang di masyarakat. Ini memperlihatkan relevansi 
dari teori konvergensi simbolis dalam menangani konflik komunikasi antar budaya.

Untuk memperdalam pemahaman komunikasi antar budaya, mari sejenak meminjam konsep penting dalam jaringan komunikasi yaitu konsep homofili dan heterofili. Suranto (2010: 49) menyatakan bahwa berdasarkan konsep homofili, orang akan cenderung nyaman untuk berinteraksi dengan individu-individu lain yang serupa dalam hal karakteristikkarakteristik sosial budaya dengannya. Dimensi-dimensi homofili tersebut dapat diklasifikasikan sebagai berikut: (1) homofili dalam penampilan, (2) homofili dalam latar belakang, (3) homofili dalam sikap, (4) homofili dalam nilai, dan (5) homofili dalam kepribadian.

Oleh karena itu, tugas penting dari pemimpin opini dalam institusi sosial atau institusi adat yang akan dibangun adalah mengaburkan pandangan kelompok kitamereka, termasuk meleburkan diri agar menjadi bagian dari masyarakat. Pengaburan tersebut dapat ditempuh dengan jalan merangkul semua elemen adat yang ada di suatu kelompok masyarakat dan membuat cabang-cabang pada tiap kelompok budaya.

Ada tanggungjawab yang diberikan pada tiap pemimpin kelompok budaya untuk menyampaikan pesan-pesan integrasi pada tiap kelompok budayanya. Banyak media yang dapat digunakan untuk menyampaikan pesan-pesan tersebut. Misalnya berkomunikasi melalui media wayang untuk masyarakat Jawa, lelakak atau pantun untuk masyarakat Sasak, dan lain sebagainya.

Sekali lagi, semua suku, agama, ras, dan golongan yang ada di Indonesia ini adalah satu keragaman yang ada dalam satu bingkai kesatuan, yaitu Negara Kesatuan Republik Indonesia. Di mana semua rakyat Indonesia telah melalui peristiwa-peristiwa yang sama di masa lalu, memiliki bahasa persatuan yang sama, serta hidup di waktu dan tempat yang sama.

\section{SIMPULAN}

Interaksi antar budaya tidak dapat dipisahkan dari interaksi interpersonal pada tiap anggota masyarakat dalam suatu kelompok sosial-budaya. Ada proses transaksi informasi yang berjalan secara dinamis pada tiap individu yang dipengaruhi oleh pengalaman dan pemaknaan individu saat berinteraksi dengan orang lain. Untuk mewujudkan hubungan yang harmonis dalam interkasi tersebut, komunikator/an dapat melakukan adaptasi sesuai dengan pengalaman dan pemahaman terhadap sifatsifat yang dimiliki. Selain itu, dibutuhkan kesadaran bahwa apa yang dilakukan oleh diri sendiri juga dinilai oleh orang lain. Kesadaran tersebut sangat penting untuk mengikis prasangka, stereotip, dan etnosentrisme yang ada pada diri individu atau masyarakat saat berinteraksi dengan budaya lain, sehingga tercipta komunikasi yang jujur.

Prasangka, stereotip, dan etnosentrisme sendiri merupakan gangguan dalam komunikasi antar budaya yang dapat menghadirkan konflik. Prasangka ialah awal dari sifat buruk dalam proses interaksi yang perlu dikendalikan. Dalam level individu, prasangka dapat dikendalikan melalui doktrinasi keluarga dan kesadaran individu itu sendiri. Sedangkan untuk level kelompok, prasangka dapat dikendalikan melalui pembentukan institusi sosial yang berwenang untuk memberikan sanksi sosial kepada siapapun yang memproduksi dan menyebarkan prasangka pada orang lain. Kendati demikian, institusi ini tidak hanya berhak untuk menghukum, namun juga memiliki kewajiban untuk memproduksi dan menyebarkan pesan yang konvergen pada tiap anggota institusi, terutama untuk daerah yang majemuk. Adapun pesan tersebut dapat berupa mitos dan kisah nyata yang bermuatan simbol kerukunan dan multikulturalisme. 


\section{DAFTAR PUSTAKA}

Blumer, H. (1969). Symbolic Interactionism: Perspective and Method. London: University of California Press, Ltd.

Bodenhausen V. Galen, Todd R. Andrew, and Richeson A. Jennifer. (2009). Handbook of Prejudice, Stereotyping, and Discrimination. Edited by Todd D. Nelson. New York: Psychology Press Taylor \& Francis Group.

Bormann, Ernest G. Knutson, Roxann L, Musolf Karen. (1997). "WHY DO PEOPLE SHARE FANTASIES? AN EMPIRICAL INVESTIGATION OF A BASIC TENET OF THE SYMBOLIC CONVERGENCE COMMUNICATION THEORY". Journal of Communication Studies, 48(03), 254-276.

Bungin, Burhan. (2014). Sosiologi Komunikasi. Jakarta: KENCANA Prenamedia Group.

Dharma, F. A. (2016). "Kritik Terhadap Teori Spiral of Silence: Komunikasi Masyarakat Madura dalam Konflik Sunni-Syi'ah di Sampang”. INFORMASI, 46(1), 1-18.

Floyd, Kory. (2006). Communicating Affection Interpersonal Behavior and Social Context. New York: Cambridge University Press.

Gono, Joyo N. S. 2011. "Resolusi Konflik". Forum, 30 (2), 86-90.

Hartley, Peter. (1999). Interpersonal CommunicationSecond Edition. New York: Routledge.

Hill, Anne, Watson, James, et., al. (2007). KeyThemes in Interpersonal Communication: Culture, Identities and Performance. Poland: the McGraw Hill companies.

Ilyas. 2014. "Kajian Penyelesaian Konflik Antar Desa Berbasis Kearifan Lokal di Kabupaten Sigi, Sulawesi Tengah”. JURNAL ACADEMICA, o6 (o1), 12131227.

Kerdchoochuen, Jiraporn. 2011. "Speaking
With A Stranger: Intercultural Classrooms' Tensions And Managing Strategies". Journal of College Theacing E Learning, 8 (9), 9-17.

Khairil, Muhammad. 2012. "Resolusi Konflik Poso dalam Perspektif Komunikasi Pendidikan Berbasis Agama dan Budaya”. Analisis. X11 (2) 409-430.

Littlejohn, Stephen W., dan Foss K. A. (2011). THEORIES Of HUMAN COMMUNICATION. Tenth Edition. Albuquerque. New Mexico: Wadsworth Publishing Company.

Mead, George, H. (1934). MIND, SELF, and SOCIETY: FROM THE STANDPOINT OF A SOCIAL BEHAVIORIST. Edited and with an introduction by Charles $W$. Morris. Chicago: THE UNIVERSITY OF CHICAGO PRESS.

Muhammad, Arni. (2005). Komunikasi Organisasi. Jakarta: Bumi Aksara.

Rutherford, J, Stuart, Andrea., et. al. (1990). IDENTITY, Community, Culture, Difference. Edited by Jonathan Rutherford. London: Lawrence \& Wishart

Samovar, Larry A., Porter, Richard E., \& McDaniel, Edwin R. (2010). Communication Between Cultures. Boston: Wadsworth.

Scott, Ruth, and Scott, W. A. (2005). Adjustment of Adolescents: Crosscultural Similarities and Differences. New York:Routledge.

Smith, John W. (1977). The Behavior of Communicating An Ethological Approach. USA: Harvard University Press.

Subroto, K. (2016). "KESULTANAN DEMAK: Negara yang Berdasar Syariat Islam di Tanah Jawa”. SYAMINA. Edisi II/Januari 2016.

Suranto. (2010). Komunikasi Sosial Budaya. Yogyakarta: Graha Ilmu.

Ting-Toomey, Stella. (1999). Communicating Across Culture. New York: The 
Ferry Adhi Dharma, Managing Intercultural Interaction and Prejudice Of The Indonesian Community...

Guildford Press

Wood, T. Julia. (2010). Interpersonal Communication: Everyday Encounters, Sixth Edition. Boston: Wadsworth.

Badan Pusat Statistik. 2016. Mengulik Data Suku di Indonesia (online). https:// www.bps.go.id/KegiatanLain/view/ id/127. Diakses pada 04 Agustus 2016, pukul 20.00 WIB. 